\title{
Infectious Disease and Antimicrobial Agents the Best Way to Use a Limited Resource
}

\author{
Mauro Luisetto* \\ European Specialist Laboratory Medicine, Hospital Pharmacist manager, Italy
}

Submission: September 19, 2017; Published: October 20, 2017

*Corresponding author: Mauro Luisetto, European Specialist Laboratory Medicine, Hospital Pharmacist Manager, Italy, Tel: 0040-269-217927,

E-mail: M.Luisetto@ausl.pc.it

Keywords: Infectious diseases, Antimicrobial agents, Clinical outcomes, Pharmaceutical industry, Drug design, Delivery systems

\section{Introduction}

\section{We can see today some critically conditions in field of infectious disease therapy:}

Few new class molecules introduced in therapy, MDR and other serious resistances rapidly expanding

Abuse or misuse of some parenteral antimicrobial out of hospital settings, new infectious disease epidemic situations, imitated economic resource by public staked orders to assign to infectious disease field. The same we observe in example the efficacy of some antivirus therapy as in HEPATIT C and the role in reducing also the liver transplant needs (Pharmacology Vs surgery strategies).

The severe infectious disease are imply often in high mortality rate in ICU and in other critical wards and the clinical pharmacists role can improve this specific rate [1,2]. The clinical patient conditions require often the less nephrotoxic dugs but with high efficacy and to adequately use saving life drugs in the right method can results in improving patient survival. Many antimicrobials are also associated with resistance pattern and all this condition need an efficacy strategy to best use this clinical resource we have today. To do this in the right way is needed multidisciplinary equips [1] with added medicinal chemistry competences to adequately set the problem.

A misuse or abuse in this approach results in dangerous situation related to severe infectious disease we can see today (Killer bacteria-superbugs). The association of clinical pharmacy and medicinal chemistry competence also at single researcher level can contribute to overtake the failure in some antimicrobial strategy. The high rate in relapses in some condition $[3,4]$ or inefficacy due by rapid residences diffusion need new strategies in drug design and drug re-design in order to improve ADME PROFILE, drug delivery systems. Modify in dynamics or other mechanism able to improve the real efficacy to the drugs.

Perhaps the creativity approach without too much bureaucracy can give the right results in this period in order to discover new pharmacological strategy as we have seen in last 2 centuries. According article : Infectious Disease Pharmaceutical Care: The Role of the Clinical Pharmacists to Improve Clinical Outcomes 2017 "Today more than past we need to improve clinical outcomes in the management of infectious disease pathology related to critical patient (septic shock, sepsis, MOF, invasive fungal infections, HIV, peritonitis, meningitis, endocarditic, osteomyelitis, pneumonia, severe UTI, proteases infections and many other).

The same way we can see the high efficacy of some new drugs in eradicate severe infectious (in example CEPATITIS), saving HIGH cost for transplant. This condition needs today an active role and permanent presence of clinical hospital pharmacist in medical equip because these kinds of pharmacological therapies highly involved in patient's health [5]." And as reported in article The Clinical Pharmacist Competence as Pharmaceutical Drug Design Tool "The clinical pharmacist specific competences added to medicinal chemistry knowledge and expertise clinical need are efficacy instruments to translate to pharmaceutical industries the modification of pharmacological molecule or the need to search new strategy in drug therapy if not efficacy as request."

According Basak et al. [6] "We hereby conclude that early detection and close monitoring of MDR, XDR, or even PDR bacterial strains must be started by all clinical microbiology laboratories 
to reduce the menace of antimicrobial resistance which is now a global problem" [7]. Ban TA Write that "Serendipity is one of the many factors that may contribute to drug discovery. It has played a role in the discovery of prototype psychotropic drugs that led to modern pharmacological treatment in psychiatry. It has also played a role in the discovery of several drugs that have had an impact on the development of psychiatry.

"Serendipity" in drug discovery implies the finding of one thing while looking for something else. This was the case in six of the twelve serendipitous discoveries reviewed in this paper, i.e., aniline purple, penicillin, lysergic acid diethylamide, meprobamate, chlorpromazine, and imipramine. In the case of three drugs, i.e., potassium bromide, chloral hydrate, and lithium, the discovery was serendipitous because an utterly false rationale led to correct empirical results; and in case of two others, i.e., iproniazid and sildenafil, because valuable indications were found for these drugs which were not initially those sought The discovery of one of the twelve drugs, chlordiazepoxide, was sheer luck [8].

Campbell writed"Serendipity, in various shades of semantic legitimacy, is abundantly evident in the history of the chemotherapy of infectious disease. We may be on the threshold of a new era of rational drug design, but most medications for infectious diseases have arisen, and continue to arise, from chance observation, clinical experience, and the empirical search for substances active against pathogens. Chance does not produce drugs; but where chance has played a pivotal role in drug discovery, the event may be considered serendipitous to a greater or lesser degree.

In a deliberate search for new drugs, it is often difficult to assess the degree to which any resulting discovery is serendipitous, and the usefulness of the term becomes debatable. Many therapeutic advances emerge from research involving animals, and a triggering "happy accident" may reside in the most basic aspects of animal care or in the most arcane knowledge of animals. The examples discussed in this article deal mostly with parasitic disease and the use of animal models in the discovery of antiphrastic agents. In this area, as in others, chance has laid the groundwork for scientific advancement and practical benefit. Although the applicability of the word serendipity to drug discovery may often be uncertain, the role played by chance should be recognized and welcomed $[9,10] . "$

\section{Discussion conclusion}

Infectious disease and antimicrobial agent use imply deep knowledge and expertise in this field by medical team and clinical pharmaceutical care principle can complete the clinician's works in more rational way preserving the activity of some critical drugs from MDR diffusion [7]. We think that using the methods of the researcher in 1800-1900 in their laboratory without a lot of burocratic rules we can obtain more relevant pharmacological molecules to introduce in therapy today. We can think also that a more rapid process in improving some chemical characteristics of some drugs is today requested and this can be reached also by single research level. This work must be favored by registrative institution in an acceptable toxicity risk level in order to have more chances in drug discovering and re-designing.

\section{References}

1. Luisetto M, Nili-Ahmadabadi B (2017) Chronic Prostatitis: The Clinical Pharmacist Role and New Delivery Systems. J Bioanal Biomed 9(2).

2. Luisetto M (2017) Infectious Disease Pharmaceutical Care: The Role of the Clinical Pharmacists to Improve Clinical Outcomes 2017. J Antimicrob Agents 3(2): DOI:10.4172/2472-1212.1000143.

3. Nili-Ahmadabadi B, Luisetto M, Nili-Ahmadabadi H, Nasser H, Mashori GR, et al. (2016) Clinical impact of pharmacist presence in ICU medical team on mortality rate. Clinicians Teamwork 1: 15-33.

4. Mauro Luisetto, Nili-Ahmadabadi B, Mashori GR (2017) The Clinical Pharmacists Main Focus 1 Applied Pharmacologist. J Antimicrob Agents 3:2.

5. Luisetto M, Nili-Ahmadabadi B (2017) The Clinical Pharmacist Competence as Pharmaceutical Drug. Design Tool Research \& Reviews: Journal of Hospital and Clinical Pharmacy 3(2).

6. Luisetto M (2016) Pharmaceutical Care in Surgery Field. Journal of Pharmaceutical Care \& Health Systems 3(3).

7. Silpi Basak, Priyanka Singh, Monali Rajurkar (2016) Multidrug Resistant and Extensively Drug Resistant Bacteria: A Study J Pathog 5.

8. Ban TA (2006) The role of serendipity in drug discovery. Dialogues Clin Neurosci 8(3):335-344.

9. Campbell WC (2005) Serendipity and new drugs for infectious disease. LAR J 46(4): 352-356.

10. Luisetto M, Behzad NA, Ghulam RM (2017) The Laboratory Right Dimension in Drug Design and Efficacy Pharmacological Molecule Modify Strategy-New Algorithm. Mod Appro Drug Des 2. 


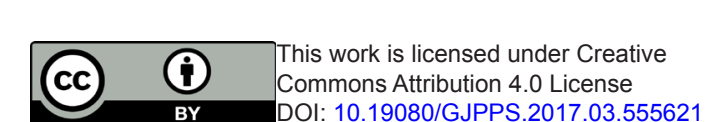
Commons Attribution 4.0 License DOI: 10.19080/GJPPS.2017.03.555621

\section{Your next submission with Juniper Publishers will reach you the below assets}

- Quality Editorial service

- Swift Peer Review

- Reprints availability

- E-prints Service

- Manuscript Podcast for convenient understanding

- Global attainment for your research

- Manuscript accessibility in different formats ( Pdf, E-pub, Full Text, Audio)

- Unceasing customer service

Track the below URL for one-step submission https://juniperpublishers.com/online-submission.php 